\title{
Speciation And Physicochemical Studies of Some Biospecific Compounds
}

\author{
Dr.S.Gaur ${ }^{1}$, Ms.K.Joshi ${ }^{2}$ \\ Coordination Chemistry Lab. Department Of Chemistry, Jai Narain Vyas University, Jodhpur \\ (Rajasthan),India-342001
}

\begin{abstract}
A green, safer, efficient, eco-friendly approach for the synthesis of novel compounds which reveal biological and spermicidal activity. The nature of the pharmacophore decides the physiological reactivity of the compound.

Keywords: Microbial, Microwave assisted, Solvent free, Spermicidal activity, Structure-activity relationship
\end{abstract}

\section{Introduction}

The basis of understanding in any projected area lies in an awareness of the relationships between the chemistry of a particular compound or group of compounds and its interaction with the body of interest or any particular metal ion. This is termed as structure-activity relationship and the mechanism by which the compound influences the biological system, is called as its mode of action. The biological action is not solely dependent on thermodynamic activity but possess some structural characteristics by orienting the functional groups into a spatial arrangement which makes it responsible for the biological response it causes. Microwave irradiation [MEC(Microwave Enhanced Chemistry) or MORE(Microwave Organic Reaction Enhancement)] has now days become a popular mode of heating, replacing the old thermal or conventional one, being more economical and environmental friendly ${ }^{[1]}$.Additional advantage is by using solvent free reaction procedure, thereby compounds formed are sufficiently pure to circumvent extensive purification. With this objective, certain stereospecific compounds were synthesised and their biological nature and toxicity were evaluated which revealed that a particular pharmacophoric group has been found to be more toxic ${ }^{[2,3]}$.

\section{Experimental}

All the chemicals and solvents were of reagent grade and were used without further purification.

\subsection{Physical Measurements}

Complexes were analysed using standard methods ${ }^{[4,5}{ }^{5}$.Molar conductance was measured using a systronics conductivity meter model NDC-732 using $10^{-3} \mathrm{M}$ solutions in DMF. Spectroscopic data were obtained using following instruments: IR spectra- Brucker model Tensor-27 spectrophotometer, NMR spectra- Hitachi Perkin-Elmer Spectrometer.

\subsection{Synthetic Routes}

Ligand 5(DPPMP) and its analogues(5a-e) were prepared by the reaction of ethylacetoacetate and phenyl hydrazine resulting in compound (1), which resulted in another compound $\mathbf{2}$ (antipyrine) on treatment with $\mathrm{CH}_{3} \mathrm{I}$. Further on treating its bromo analogue(3), with $\left(\mathrm{CH}_{3}\right)_{2} \mathrm{NH}$ gave a amino compound (4) (Aminopyrine). This when reacted with substituted amino phenol resulted in different analogues (5a-e) (SCHEME 1). The analytical parameters determined are satisfactory. The melting points are determined in open capillary and are uncorrected. The purity of the samples is tested with TLC. Distinct peaks in the IR and NMR regions support the structure of the compounds.

\subsubsection{3-methyl-1- phenyl pyrazol-5- one (1) (MPP)}

Equimolar quantities of ethylacetoacetate and phenyl hydrazine were mixed up and was microwave irradiated for about $8 \mathrm{~min}$. The colour of the reaction mixture changed into dark brown and finally crystallized into a solid mass m.p- $121^{\circ} \mathrm{c}$, yield $72 \%, \mathrm{R}_{\mathrm{f}}=0.78$;

IR $v\left(\mathrm{~cm}^{-1}\right): 1614(\mathrm{C}=\mathrm{N}), 3000($ aromatic $\mathrm{CH}), 1710(\mathrm{C}=\mathrm{O}), 1530(\mathrm{~N}-\mathrm{N})$

${ }^{1} \mathrm{HNMR}\left(\mathrm{CDCl}_{3}\right) \delta:=\mathrm{C}-\mathrm{CH}_{3}\left(\right.$ allylic) $1.6,-\mathrm{CH}_{2}$ (methylene) $1.3,-\mathrm{C}_{6} \mathrm{H}_{5}$ (phenyl) 7.2.

Percentage of elements; found (calculated) C-68.91(68.96); H-5.70(5.74);

N-16.02(16.09); O-9.13(9.19).

\subsubsection{2, 3-dimethyl -1- phenyl-pyrazol-5-one (2) (DPP) \\ Compound (1) and $\mathrm{CH}_{3} \mathrm{I}$ gave the compound (2) (7 min) m.p. $-130^{\circ} \mathrm{c}$, yield $71 \%, \mathrm{R}_{\mathrm{f}}=0.87$; \\ IR $v(\mathrm{~cm}-1): 1710(\mathrm{C}=\mathrm{O}), 1218(\mathrm{C}-\mathrm{N}), 1650(\mathrm{C}=\mathrm{C}), 1535(\mathrm{~N}-\mathrm{N})$}


${ }^{1} \mathrm{HNMR}\left(\mathrm{CDCl}_{3}\right) \delta:-\mathrm{CH}_{3}$ (methyl) 1.9,=C-H(vinylic) 5.2, N-CH $\mathrm{CH}_{3} \sim 2.10, \mathrm{~N}-\mathrm{Ph} \sim 7.9$.

Percentage of elements; found( calculated) C-70.16(70.21); H-6.88(6.91);

N-14.82(14.89); O-8.46(8.55).

2.2.3. Bromo analogue of compound (3)

$\mathrm{Br}$ was introduced at 4 position $(6 \mathrm{~min}) \mathrm{m} . \mathrm{p}-150^{\circ} \mathrm{c}$, yield $70 \%, \mathrm{R}_{\mathrm{f}}=0.89$.

IR $v\left(\mathrm{~cm}^{-1}\right): 1678(\mathrm{C}=\mathrm{C}), 1715(\mathrm{C}=\mathrm{O}), 1216(\mathrm{C}-\mathrm{N}), 508(\mathrm{C}-\mathrm{Br})$.

${ }^{1} \mathrm{HNMR}\left(\mathrm{CDCl}_{3}\right) \delta$ : $-\mathrm{CH}_{3}$ (methyl) 1.9, N-CH $\mathrm{CH}_{3} \sim 2.11$, N-Ph 7.8.

Percentage of elements; found( calculated) C-49.39(49.43); H-4.07(4.11);

N-10.42(10.48); O-5.94(5.99).

\subsubsection{Aminopyrine (compound 4)}

The Br group was replaced by $\mathrm{N}\left(\mathrm{CH}_{3}\right)_{2}(8 \mathrm{~min}) \mathrm{m} \cdot \mathrm{p}-158^{\circ} \mathrm{c}, \mathrm{R}_{\mathrm{f}}=0.90$, yield $=68 \%$.

IR $v\left(\mathrm{~cm}^{-1}\right): 1665(\mathrm{C}=\mathrm{C}), 1713(\mathrm{C}=\mathrm{O}), 1217(\mathrm{C}-\mathrm{N})$.

${ }^{1} \mathrm{HNMR}\left(\mathrm{CDCl}_{3}\right) \delta$ : $-\mathrm{CH}_{3}$ (methyl) 1.8, N-CH $\mathrm{CH}_{3} \sim 2.11, \mathrm{~N}-\mathrm{Ph} \sim 7.8,\left(\mathrm{CH}_{3}\right)_{2} \mathrm{~N} \sim 2.06$

Percentage of elements; found( calculated) C-67.48(67.53); H-7.30(7.35);

N-18.13(18.18); O-6.87(6.92).

\subsubsection{2, 3-dimethyl-4-(N,Ndimethyl amino)-1-phenyl pyrazolimino-2-methyl phenol(DPPMP) (5)}

Compound (4) was microwaved with substituted aminophenol at position 4 by pharmacophores $\mathrm{NO}_{2}$ (6 min), $\mathrm{Cl}(5 \mathrm{~min}), \mathrm{Br}(8 \mathrm{~min}), \mathrm{OH}(10 \mathrm{~min}), \mathrm{OCH}_{3}(12 \mathrm{~min})$ and corresponding substituted compounds were obtained. $\mathrm{NO}_{2}$ (m.p $166^{\circ} \mathrm{c}, \mathrm{R}_{\mathrm{f}}=0.84$, yield-70\%); $\mathrm{Cl}\left(\mathrm{m} . \mathrm{p}-162^{\circ} \mathrm{c}, \mathrm{R}_{\mathrm{f}}=0.72\right.$,yield-68\%); $\mathrm{Br}\left(\mathrm{m} . \mathrm{p}-168^{\circ} \mathrm{c}, \mathrm{R}_{\mathrm{f}}\right.$ $=0.82$,yield $-78 \%) ; \mathrm{OH}\left(\mathrm{m} \cdot \mathrm{p}-161^{\circ} \mathrm{c}, \mathrm{R}_{\mathrm{f}}=0.83\right.$, yield $\left.=75 \%\right) ; \mathrm{OCH}_{3}\left(\mathrm{~m} . \mathrm{p}-148^{\circ} \mathrm{c}, \mathrm{R}_{\mathrm{f}}=0.73\right.$, yield $\left.=62 \%\right)$

IR $v\left(\mathrm{~cm}^{-}{ }^{1}\right): 1610(\mathrm{C}=\mathrm{N}), 3300(\mathrm{OH}), 712(\mathrm{C}-\mathrm{Cl}), 515(\mathrm{C}-\mathrm{Br}), 1148(\mathrm{C}-\mathrm{O}-\mathrm{C}), 1538,1330\left(\mathrm{C}-\mathrm{NO}_{2}\right)$

${ }^{1} \mathrm{HNMR}\left(\mathrm{CDCl}_{3}\right) \delta$ : $\mathrm{Ph}-\mathrm{OH}$ (phenolic) 6.1, $\mathrm{Ar}-\mathrm{CH}_{3}$ (Benzylic) 2.6, $\mathrm{OCH}_{3}$ (methoxy) 3.5

Percentage of elements; found(calculated) C-71.37(71.42); H-7.11(7.14); N-16.61(16.66); O-4.69(4.76)

\subsection{Biological Studies}

\section{Results And Disscussion}

\subsubsection{Antibacterial activity}

All the compounds 5a-e were evaluated for their antibacterial parameters against(gram+ve) S.aureus,

S.epidermidis \& ( gram-ve) P.mirabilis, P.aeruginosa with Ampicillin as reference.

3.1.2 Antifungal activity

A.niger,C.albicans,F.oxysporum were taken for the antifungal studies, with mycostatin as reference material.

Both the studies were conducted at $1000,800,400,200$ ppm concentrations by disk diffusion method ${ }^{[6,7]}$ and compounds showed good result at 1000ppm concentration.

\subsubsection{Spermicidal Activity}

Sperm motility scheme ${ }^{[8]}$ was undergone to observe the effect of the synthesised compounds (5a-e). The effect was observed under $40 \mathrm{x}$ magnification of light microscope in a cell counting chamber, For that 25 $\mu \mathrm{L}$ solution (compound+ alcohol) was added to the $25 \mu \mathrm{L}$ semen.

\section{Observations}

The presence of electron donating groups such as methoxy and hydroxyl make the ligand more potent donor and yet showed antimicrobial activity. And the compounds having pharmacophores such as chloro, bromo, nitro exhibited more activity on the bacteria and fungi. The toxicity was found to be highest for $\mathrm{NO}_{2}$ group.[Fig-1]

The addition of the compound to semen produces a reduction of sperm motility in $\mathrm{HF}$ cattle spermatozoa. At one concentration (graph of 100ppm), the rates were found to be different with time [Fig 2].

\section{Analysis Of The Compounds}

The biological parameters revealed that all the synthesized compounds have a structure activity relationship (SAR) because their activity varies with substitution ${ }^{[9-11]}$ Compounds having pharmacophores such as $\mathrm{Cl}, \mathrm{Br}, \mathrm{NO}_{2}$ showed higher activity than the others $\left(\mathrm{NO}_{2}\right.$ being the highest).Thus on the basis of SAR, electron withdrawing nature of the substituted group has a key role in deciding the physiological reactivity of the compound..$^{[12-14]}$ 


\section{Acknowledgment}

The authors are thankful to the chemist, forensic laboratory, jodhpur for offering needful assistance for the evaluation of biological studies and elemental analysis.

\section{References}

[1] M.Jida, R.Deprez-Poulain, S Mlaguim, P.Roussel, F.Agbosson-Niedercorn, B.Dprez and G.Laconde, Green Chemistry,12,2010,961

[2] S.Sharma, A.Sharma and H.Madam, Indian J.Hetrocyclic Chem,19,2010,337

[3] S.Sharma, R.Jain, V.Sharma and C.Chawlal, J.Indian Chem.Soc, 90,2013,221

[4] S.Gaur, R.Purohit, M.Ranka, J.Indian Council Chem,24(2),2007, 51

[5] S.Gaur, B.Sharma, J Indian Chem Soc,80, 2003,841

[6] S.Sharma, R.Jain, V.Sharma and C.Chwala, J Indian Chem Soc, 90, 2013, 221

[7] V. Sharma, M. Borse, and S. Devi, J Dispersion Sci \& Technology, 26, 2005, 421.

[8] S. Chongthamakum, E.Ekavipat, B. Saintwonges, and K. Pavasuthipaisit, Contraception, 34,1986, 323.

[9] D.Cunningham, J. Fitzgerald and M. Little, J Chem Soc Dalton Trans, 1987, 2261.

[10] D.Cunningham, J.F.Gallagher, T.Higgins, P.Mc Ardle and D.Sheerin, J Chem Soc Chem Commun, $1991,432$.

[11] M.Asadi, Kh.Aein Jamshid and A.H.Kyanfar, Inorg Chem Acta, 360, 2007, 1725

[12] A.H.Sarvestani, A.Salimi, S.Mohebbi and R.Hallaj, J Chem Res, 3, 2005, 190.

[13] A.K. Bose, B.K.Bainik, C. mathur, D. R. Wagle and M.S.Manhas, Tetrahedron, 56, 2000, 5603

[14] E.G.Jager, K. Schuhmann and H.Goris, Inorg Chem Acta, 255, 1997, 295

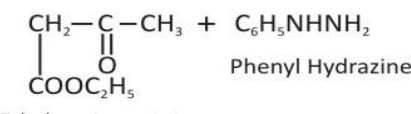

Ethyl acetoacetate

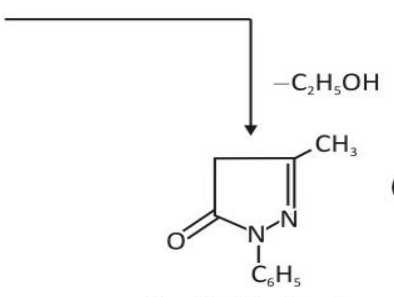<smiles>Cc1ccc(I)cc1O</smiles><smiles></smiles>

(5)

$$
\text { 3-methyl-1-phenyl }
$$

pyrazol-5-one<smiles>Cc1cc(=O)n(-c2ccccc2)n1C</smiles>

2,3 dimethyl 4-(N,N dimethyl amino) 1-phenyl pyrazolimino-2-methyl<smiles>Cc1ccc(N)cc1O</smiles>
phenol (DPPMP)

Antipyrine

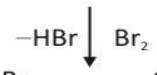<smiles>CCCCCCCCn1c(=O)c(Br)c(C)n1C</smiles>

5-amino-2-methy phenol

Aminopyrine

$5 \mathrm{a}=\mathrm{NO}_{2}$

$5 \mathrm{~b}=\mathrm{Cl}$

$5 \mathrm{c}=\mathrm{Br}$

$5 \mathrm{~d}=\mathrm{OH}$

$5 \mathrm{e}=\mathrm{OCH}_{3}$

(SCHEME 1) 

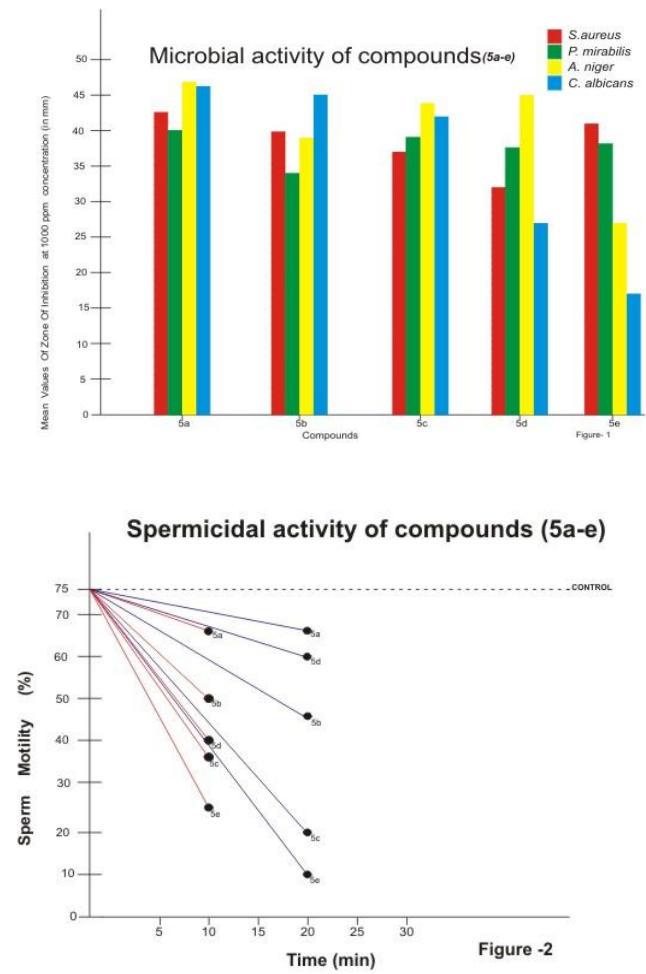